\title{
MODEL FOR PREDICTING ACADEMIC PERFORMANCE THROUGH ARTIFICIAL INTELLIGENCE
}

Silva, Jesús; Romero, Ligia; Solano, Darwin; Fernández, Claudia; Lezama, Omar Bonerge Pineda; Rojas, Karina

\begin{abstract}
During the transit of students in the acquisition of competencies that allow them a good future development of their profession, they face the constant challenge of overcoming academic subjects. According to the learning theory, the probability of success of his studies is a multifactorial problem, with learning-teaching interaction being a transcendental element (Muñoz-Repiso and Gómez-Pablos in Edutec. Revista Electrónica de Tecnología Educativa 52: a291-a291 (2015), [1]. This research describes a predicative model of academic performance using neural network techniques on a real data set.
\end{abstract}

\section{Keywords}

Academic performance, Big data, Neural networks, learning analytics 